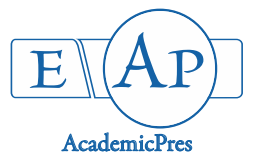

Ibigbami T and Adeonipekun A (2020)

Notulae Scientia Biologicae 12(3):729-740

DOI: $10.15835 / \mathrm{nsb} 12310768$

Research Article

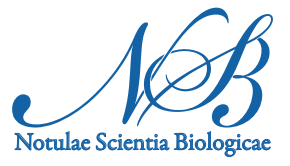

\title{
Comparative aeropalynology of two communities in Lagos State, southwestern Nigeria
}

\author{
Temidayo IBIGBAMI*, Adegbenga ADEONIPEKUN
}

\author{
University of Lagos, Faculty of Science, Department of Botany, Lagos, \\ Nigeria; dayoomooba@gmail.com (*correspondingauthor);pladeonipekun@yahoo.com
}

\begin{abstract}
Pollen allergy is an abnormal response of the immune system to certain pollen grains and these reactions are gradually on the increase all around the world. The need for consistent and accurate data on aero-pollen density as well as the meteorological conditions under which they are prevalent is imperative for appropriate management of allergic conditions in hypersensitive persons. Therefore, to identify the 'culprit' pollen related to allergy cases in Lagos, two locations, Ipaja and Ikeja were sampled. Aero-samplers were harvested weekly from February 2016 to July 2016. On the samples collected, meteorological data and clinical data were assessed against pollen counts. A total of 2,048 pollen count was recorded for Ipaja while Ikeja had 820 with main taxa being Amaranthaceae, Poaceae and Euphorbiaceae. Weekly pollen counts were highest in weeks 8 and 10 (April) at Ipaja and Ikeja respectively and lowest in weeks 22 and 24 (June) at Ipaja and Ikeja respectively. Temperature positively correlated with pollen sum at Ipaja, relative humidity and wind speed correlated negatively with pollen sum while a positive correlation existed between pollen density, cold and catarrh at both locations though not statistically significant. Poaceae, Amaranthaceae and Alchornea cordifolia have been confirmed to be allergenic, therefore hypersensitive individuals are to be informed to take precautions at preseason of the pollen peaks (just before weeks 8 and 10). A year or two years sampling is however needed to generate a more comprehensive data. This is the first record of weekly aerobiological data in Nigeria.
\end{abstract}

Keywords: aeropalynology; allergy; pollen allergy; pollinosis; pollen

\section{Introduction}

It has been established for more than a century that pollen grains are responsible for many allergic diseases, such as hay fever, asthma, allergic rhinitis, and atopic dermatitis (Knox, 1993; Agashe, 1994). Pollen allergy (hay fever, pollinosis) is a common disease caused by a hypersensitivity reaction of the respiratory tract and eye conjunctivae to pollen grains (Singh and Mathur, 2012). Friedhoff (1986) had remarked that in the last quarter of the twentieth century, there was an increase in population of hypersensitive persons as a result of air pollutants from anthropogenic activities. Therefore, there is increasing attempts globally to evaluate the pollen content of the atmosphere. This is important because the useful data that will be generated are vital tools in the monitoring, diagnosis and treatment of pollinosis. The atmospheric concentration of pollen and spores vary according to climate, geography and vegetation (Claypoole et al., 1983) hence the need to evaluate as many 
localities as possible so as to have data of all areas available for prediction and monitoring as well as for scientific research purposes.

Statistics on the existence and prevalence of allergenic airborne pollen obtained from both aerobiological and allergological studies make it possible to construct pollen calendar with the approximate flowering periods of the plants in the sampling area (D'Amato et al., 2007). In this way, even though pollen production and dispersal from year to year depend on the patterns of pre-season weather and the conditions prevailing at the time of a thesis, it is usually possible to forecast the chances of encountering high atmospheric allergenic pollen concentrations in different areas. Basic data for comparative pollen analysis and testing is largely unavailable in most parts of Africa. Considering the high prevalence of allergic disease in sub-Saharan Africa and some other parts of the world, there is a huge need to help allergy sufferers through extensive aero-palynological research for monitoring and drug manufacture.

In Nigeria, Agwu and Osibe (1992), Agwu (1997) and Njokucha (2006) have provided aero-flora information for the southeast region. Njokucha (2006) recognized three seasons (dry season, rainy season and late rainy season to early dry/harmattan season) from the analysis of airborne pollen grains at two different sampling heights $(1.8 \mathrm{~m}$ and $15 \mathrm{~m}$ ) at Nsukka, Southeast Nigeria. It was found that the sampler with $15 \mathrm{~m}$ had higher pollen concentration than the $1.8 \mathrm{~m}$ sampler height had more pollen concentration than the $1.8 \mathrm{~m}$ sampler. The presence of long-distance transported pollen indicating wind as a major factor responsible for pollen dispersal and concentration. In the southwest, there has been a progressive work in aeropalynology ranging from a four-month study within the University of Lagos, Lagos State by Adekanmbi and Ogundipe (2010) to the study of the haze dust during March 2010 at Ayetoro-Itele Ota, Ogun state by Adeonipekun and John (2011). After these works, several others which include Adeonipekun (2012), Adeniyi et al. (2014), Adeonipekun et al. (2016) and Ajika et al. (2015) have improved our knowledge on the aeropalynology of Nigeria.

In the four-month (February, March, April and May) study of Adekanmbi and Ogundipe, (2010) the highest number of palynomorphs was recorded during the month of May and this corresponds to the peak of wind speed during the sampling months. This shows that wind speed plays an important role in the dispersal of palynomorphs. Adeonipekun and John (2011) encountered typical savanna pollen taxa in secondary rain forest area which was quite unusual in March 2010. There was a substantial difference in the pollen taxa recorded in the same month and location for the following year 2011 when high diversity but low abundance of diatoms was recorded (Adeonipekun, 2012). Therefore, to generate an aero-flora record for comparative study of an area, the seasonal distribution and abundance of aero-flora over a period of year is needed not just a month or four. The one-year aero-palynological study in Shomolu Local Government Area of Lagos State by Adeniyi et al. (2014) revealed four pollen seasons distribution. The first season spans between January and May, which was marked with the abundance of Amaranthaceae and Alchornea cordifolia. The second season, June and July, is a short period and it is dominated by Cyperaceae and Amaranthaceae. While the short dry and wet season of August and September had more pollen dominating which are Casuarina, Poaceae, Cyperaceae and Amaranthaceae. The last season (October-December) which had the highest pollen count is marked by Poaceae. There was a significant positive correlation of Casuarina sp. and Cyperaceae pollen with wheezing cough occurrence, which suggests the high potency of these taxa in causing allergy. Adeniyi et al. (2014) is the first work that ever correlated aero-flora record with allergic cases in Nigeria. The research also revealed that Pollen sum show negative correlations with rainfall and relative humidity which is logical since water droplets wash away pollen particles.

Adeonipekun et al. (2016) carried out a one-year (February 2011 - January 2012) aero-palynological survey of Ayetoro-Itele Ota, Southwest Nigeria. Adeonipekun et al. (2016) recognized four aero-floral seasons which are January - March (dry Typha - Alchornea), April - July (wet Verrucate spore - Asteraceae), August September (windy Bissacate) and October - December (wet/dry Acrostichum - Dryopteris). The work revealed that meteorological parameters impact the aeropalynofloral component in different ways. Rainfall which is a strong determinant factor of the Nigerian climate, had a negative influence on the density of aero-flora during 
its onset and cessation months (April and October). While the impact of wind speed was felt most in August September and March with the density of bissacate pollen and charred Poaceae cuticles. Adeonipekun et al. (2016) recorded Podocarpus-like pollen, the first ever in aero-palynological sampling in Nigeria which further substantiates the importance of wind speed in the dispersal of pollen. This is because this particular pollen is not native to the surrounding vegetation of sampling area and Nigeria as a whole. It is therefore necessary to sample for two - three consecutive years in other to monitor this pollen to be useful for pollen calendar construction (Adeonipekun et al.2016).

To gain further insight and contribute to the development of aeropalynology of Lagos state, this study therefore evaluates the distribution of aeroplankton in selected parts of the state and assesses the effects of meteorological factors on their distribution. It specifically focuses on the weekly collection of aeropalynomorphs of two communities in Lagos in other to generate a weekly pollen calendar for these communities, relate the airborne pollen grains and spores to the meteorological parameters under which they are prevalent and possibly identify culprit allergenic airborne pollen.

\section{Materials and Methods}

\section{Studyarea}

Ikeja is located within Ikeja Local Government Area, Lagos State (Figure 1). It is the commercial hub of the state and home to a lot of corporate organizations and vintage residential settlements. Worthy of note is the very popular Computer Village which is the largest Information Technology (IT) market in West Africa. Ikeja has an area of $49.92 \mathrm{~km}^{2}$, on longitude and latitude $\mathrm{N} 0635^{\prime}$ and E $0320^{\prime}$ respectively. It has a population size of 648,720 according to the 2006 census (National Population Commission of Nigeria, 2006). The vegetation of southwest of Nigeria straddles between tropical rainforest, Guinea savanna and Mangrove swamp. Urbanization has almost completely rid Ikeja of its natural vegetation. Vegetation is very scanty around Ikeja save the reserved areas close to the International and local Airport. Ipaja on the other hand is a semi-urban area located within Alimosho Local Government Area in the state though densely populated, it still has lush vegetation of shrubs, herbs (Alchornea cordifolia, Amaranthus, Gomphrena), trees (Elaeis guineensis, Cocos nucifera, Terminalia cattapa), grass (Panicum maximum, Cynodon dactylon) and freshwater swamp covering a wide mass of land area. Crop farming is a common sight within Ipaja and its environment. Ipaja has an area of about $17.92 \mathrm{~km}^{2}$ per square, on longitude and latitude N 636 '38" and E 3 15' 21" with Alimosho Local Government having 1,319,571 total population (National Population Commission of Nigeria, 2006).

The two sampling locations have a tropical wet and dry climate controlled by a tropical monsoon climate with the normal dry and wet seasons. The harmattan winds from the Sahara Desert is the major driver of the longer dry season while the wet season is characterized by rainfall which influences the temperature. The raining season occurs twice with the highest rainfall (average of $400 \mathrm{~mm}$ ) between April and July and low rainfall (average of $200 \mathrm{~mm}$ ) between September and November (Longe et al., 1987). There is a short dry season" in August known as the "August break" and a longer dry season from December to March, which is termed the harmattan period. The harmattan period is characterized by cold and dry weather, often windy with low relative humidity and rainfall (average of $25 \mathrm{~mm}$ ).

\section{Pollen collection}

Aeropalynological samples were collected weekly from the two locations (Ikeja and Ipaja) for a period of six months straddling partly dry season and whole of wet season (Feb $13^{\text {th }}$ - July $\left.30^{\text {th }}\right)$. A gravitational aerosampler Gbenga-2 (Adeonipekun 2012) was deployed at the two locations on a $2 \mathrm{~m}$-high stand. A mixture of formaldehyde and glycerol was used as the medium in the aero-floral sampler (Adeonipekun, 2012). The recovered residue was subjected to acetolysis according to Erdtman (1969) and microscopically studied quantitatively and qualitatively. 


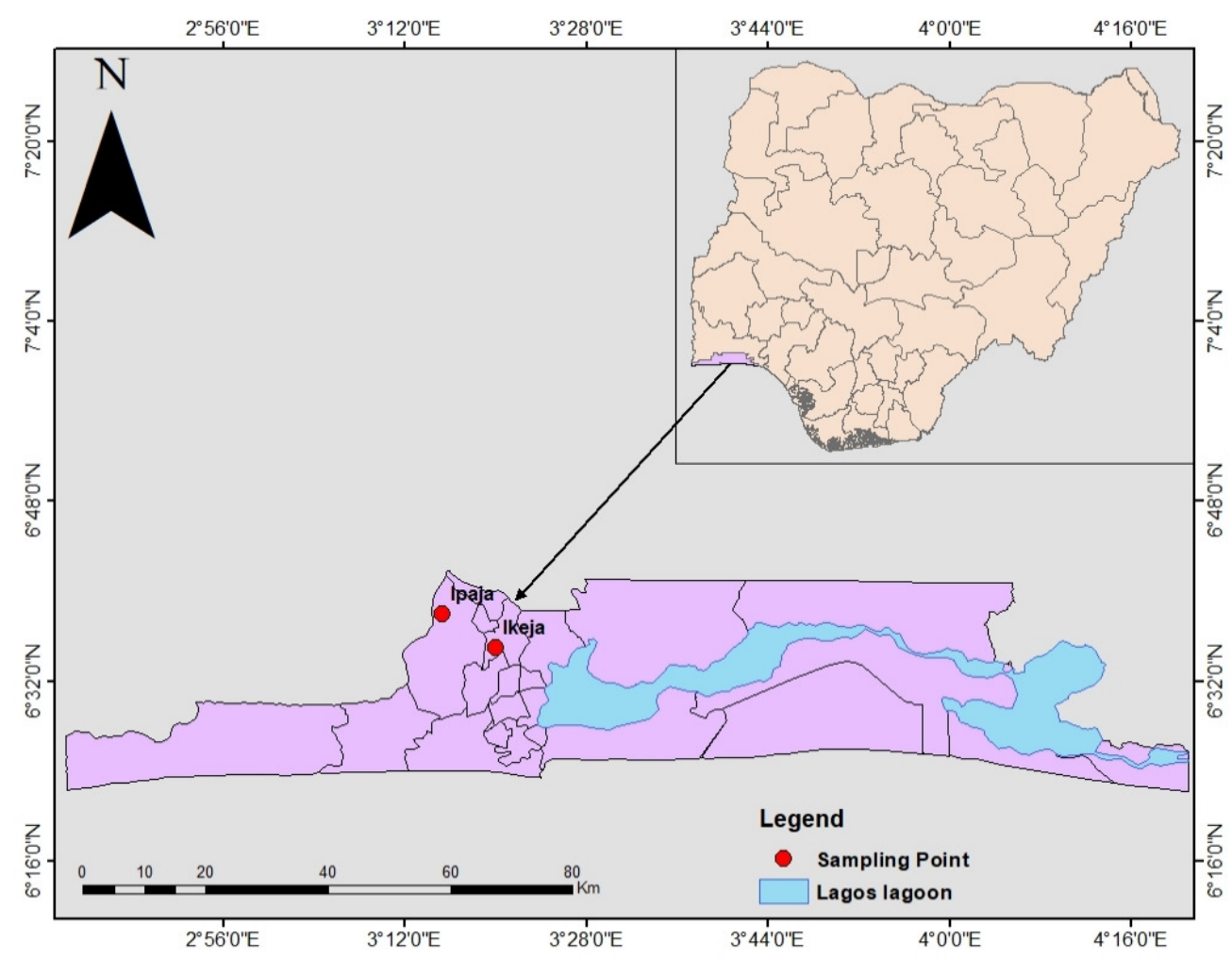

Figure 1. Location map showing sampling sites (red solid circles) in Ikeja and Ipaja, Lagos State

\section{Collection of weather parameters}

Weekly meteorological data was provided by the Nigeria Meteorological Agency, Oshodi Lagos which included average temperature, average mean rainfall, average relative humidity and average wind speed for the study areas. The pollen density was compared to meteorological data to identify potential relationships with the use of parametric statistical analysis by Pearson's correlation test.

\section{Clinical data collection}

Reported cases of asthma, common cold and catarrh were collected at Adefemi Medical Center, a private clinic in Ipaja. There was no record for Ikeja as all the hospitals approached had no record of such data.

\section{Results}

A total of 2,868 pollen and spores from 21 families were recorded. Ipaja had the highest palynomorph counts of 2,048 while Ikeja had 820. Pollen grains (14 families) dominate over pteridiophytes spores (seven families) in all the months sampled. The weekly highest values of pollen grains were recovered during April for both locations (Ipaja - 257 and Ikeja - 30) (Appendices 1 and 4). Poaceae recorded dominance at both locations all through the sampling period and recorded peaks in (weeks: 4, 13 and 20 at Ipaja and weeks 10, 17 and 18 at Ikeja) March, April and June. Alchornea cordifolia was also dominant through the sampling period with peaks recorded at week 13 (April) for both locations (Appendices 1 - 4). Worthy of note is the sudden appearance of Amaranthaceae at Ipaja during week 5 (March), hitting its peak at week 8 (April) and gradually decreased but did not fade out. While at Ikeja, Amaranthaceace was present throughout the sampling period but it was not 
abundant as recorded at Ipaja. Elaeis guineensis was recorded all through the sampling period at Ipaja location alone (Table 1) (Figures 2-4).

Table 1. Percentage composition of airborne Pollen grains at Ipaja and Ikeja locations

\begin{tabular}{|c|c|c|c|c|}
\hline Pollen & $\begin{array}{c}\text { Pollen counts } \\
\text { at Ipaja }\end{array}$ & $\begin{array}{c}\text { \% Total counts } \\
\text { (Ipaja) }\end{array}$ & $\begin{array}{c}\text { Pollen counts at } \\
\text { Ikeja }\end{array}$ & $\begin{array}{c}\text { \% Total counts } \\
\text { (Ikeja) }\end{array}$ \\
\hline Alchornea cordifolia & 75 & 5.3 & 86 & 32.7 \\
\hline Asteraceae & 16 & 1.1 & 7 & 2.6 \\
\hline Amaranthaceae & 844 & 59 & 28 & 10 \\
\hline Casuarina equisetifolia & 1 & 0.007 & 1 & 0.4 \\
\hline Cyperaceae & 23 & 1.6 & 13 & 4.8 \\
\hline Combretaceae & - & - & 1 & 0.4 \\
\hline Commelina & 2 & 0.01 & - & - \\
\hline Euphorbiaceae & 15 & 1 & 1 & 0.4 \\
\hline Elaeis guineensis & 26 & 1.8 & - & - \\
\hline Gomphrena globose & - & - & 1 & 0.4 \\
\hline Malvaceae & - & - & 2 & 0.7 \\
\hline Mimosaceae & 9 & 0.06 & 1 & 0.4 \\
\hline Moraceae & - & - & 1 & 0.4 \\
\hline Nymphaea lotus & 13 & 0.9 & 1 & 0.4 \\
\hline Poaceae & 401 & 28 & 121 & 44.6 \\
\hline Rubiaceae & 1 & 0.007 & - & - \\
\hline Sapotaceae & - & - & 6 & 2.2 \\
\hline Typhaspp. & 2 & 0.01 & - & - \\
\hline Tridax procumbens & - & - & 1 & 0.4 \\
\hline
\end{tabular}

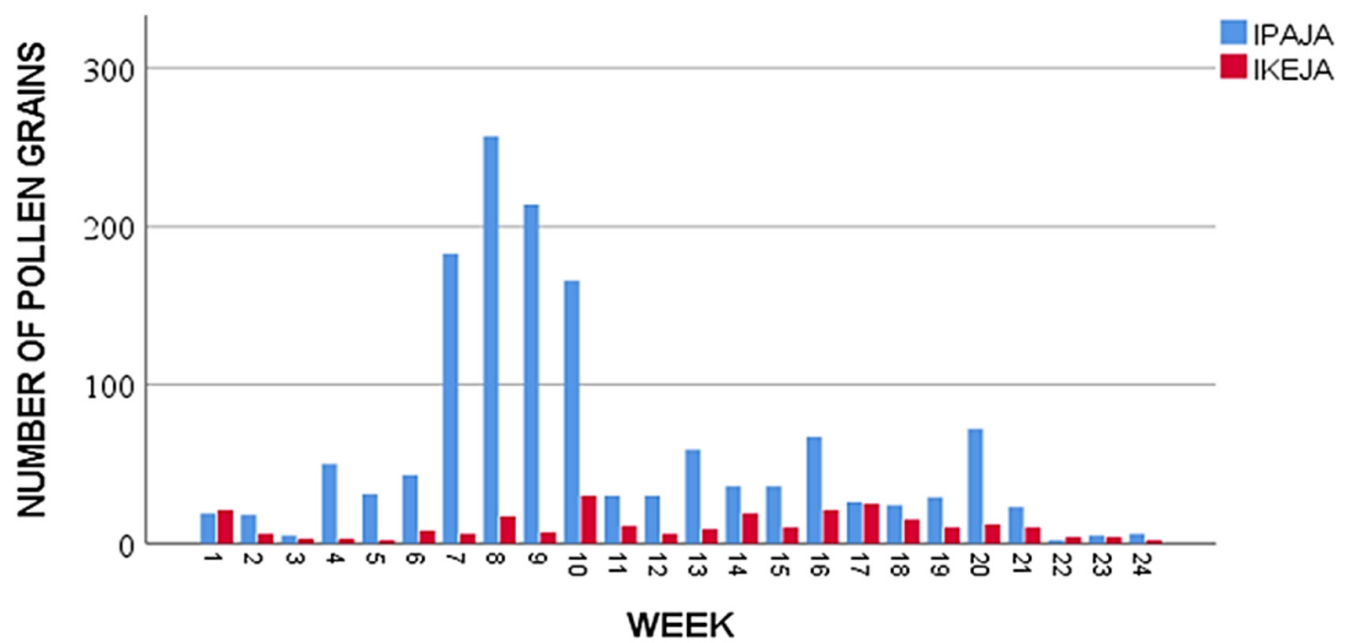

Figure 2. Chart showing the weekly distribution of pollen in the two locations in Lagos 


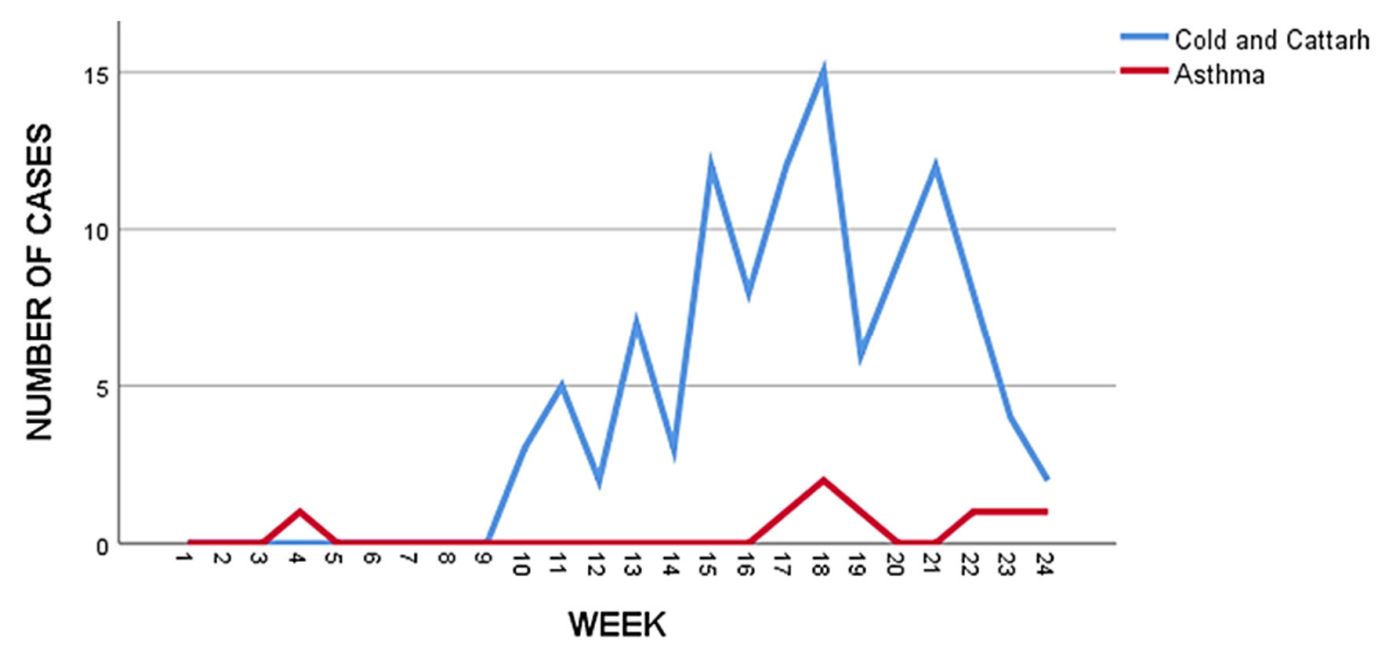

Figure 3. Line graph showing the number of clinical data

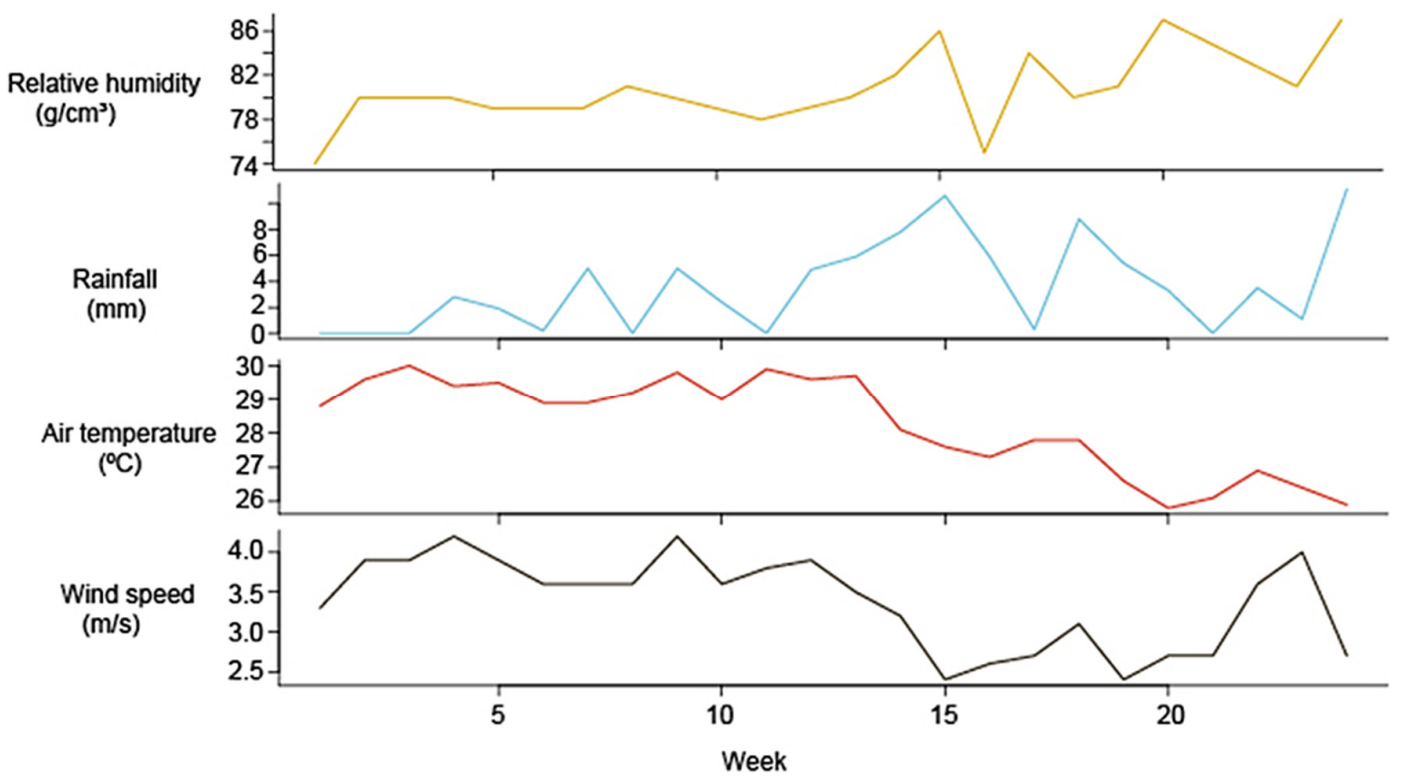

Figure 4. Line graph showing the distribution of the meteorological factors

The least abundant pollen grains were Casuarina sp. and Rubiaceae at Ipaja while, Gomphrena globose, Combretaceae, Casuarina sp., Moraceae, Mimosaceae and Nymphaea lotus were recorded at Ikeja with all occurring once. Among the pteridophytes spores, laevigate spore was dominant at Ipaja and Dryopteris was dominant at Ikeja. Of note is the recovery of fungal spores (they are associated with plant diseases and pollinosis in man) which were abundant at both locations (Ipaja -406 and Ikeja -113, Appendices 3-4) and evenly distributed through the sampling period but recorded higher values during the wet months. From the value of the correlation coefficient $(r=0.019)$, it was discovered that weekly pollen sum of Ikeja positively correlated with rainfall and negatively correlated with relative humidity, air temperature and wind (Table 2). Furthermore, correlation coefficient value $(\mathrm{r}=0.053)$ of weekly pollen sum of Ipaja positively correlated with temperature and rainfall but negatively correlated with relatively humidity and wind speed, though it is not statistically significant (Table 3). 
Table 2. Relationship between the weekly sum of pollen and meteorological factors at Ikeja study location in Lagos at $95 \%$ confidence interval $(\mathrm{p}<0.05)$

\begin{tabular}{|c|c|c|c|c|c|}
\hline \multirow{2}{*}{ IKEJA } & $\begin{array}{c}\text { Pearson } \\
\text { correlation }\end{array}$ & $\begin{array}{c}\text { Wind } \\
\text { speed }\end{array}$ & $\begin{array}{c}\text { Relative } \\
\text { humidity }\end{array}$ & $\begin{array}{c}\text { Air } \\
\text { temperature }\end{array}$ & Rainfall \\
\cline { 3 - 6 } & Sig. (1-tailed) & 0.009 & -0.210 & -0.123 & 0.019 \\
\hline $\begin{array}{c}\text { Weekly pollen } \\
\text { sum }\end{array}$ & $\mathrm{N}$ & 20 & 0.187 & 0.302 & 0.468 \\
\hline & & 20 & 20 & 20 \\
\hline
\end{tabular}

Table 3. Relationship between the weekly sum of pollen and meteorological factors at Ipaja study location in Lagos at $95 \%$ confidence interval $(\mathrm{p}<0.05)$

\begin{tabular}{|c|c|c|c|c|c|}
\hline \multirow{2}{*}{ IPAJA } & \multirow{2}{*}{$\begin{array}{c}\text { Pearson } \\
\text { correlation }\end{array}$} & $\begin{array}{c}\text { Wind } \\
\text { speed }\end{array}$ & $\begin{array}{c}\text { Relative } \\
\text { humidity }\end{array}$ & $\begin{array}{c}\text { Air } \\
\text { temperature }\end{array}$ & Rainfall \\
\cline { 3 - 6 } & -0.237 & -0.097 & 0.053 & 0.147 \\
\hline Weekly pollen & Sig. (1-tailed) & 0.157 & 0.341 & 0.412 & 0.268 \\
\hline & $\mathrm{N}$ & 20 & 20 & 20 & 20 \\
\hline
\end{tabular}

Significant $(\mathrm{p}<0.05)$ negative correlation was recorded for weekly pollen sum at Ikeja when compared with asthma cases while there was a positive correlation with cold and catarrh cases (Table 4 ). The correlation coefficient value was positive though not statistically significant when pollen sum at Ipaja was related with asthma but was negatively correlated with cold and catarrh (Table 5).

Table 4. Relationship between the weekly sum of pollen and clinical data at Ikeja study location in Lagos at $95 \%$ confidence interval $(\mathrm{p}<0.05)$

\begin{tabular}{|c|c|c|c|}
\hline \multirow{2}{*}{ IKEJA } & $\begin{array}{c}\text { Pearson } \\
\text { correlation }\end{array}$ & Cold and catarrh & Asthma \\
\cline { 3 - 4 } & Sig. (1-tailed) & 0.440 & -0.030 \\
\hline Weekly pollen & $\mathrm{N}$ & 0.026 & 0.449 \\
\hline & 20 & 20 \\
\hline
\end{tabular}

Table 5. Relationship between the weekly sum of pollen and clinical data at Ipaja study location in Lagos at $95 \%$ confidence interval $(\mathrm{p}<0.05)$

\begin{tabular}{|c|c|c|c|}
\hline \multirow{2}{*}{ IPAJA } & $\begin{array}{c}\text { Pearson } \\
\text { correlation }\end{array}$ & Cold and catarrh & Asthma \\
\cline { 3 - 4 } & Sig. $(1$-tailed $)$ & 0.166 & -0.345 \\
\hline Weekly pollen & $\mathrm{N}$ & 0.242 & 0.068 \\
\hline & 20 & 20 \\
\hline
\end{tabular}

\section{Discussion}

The Ipaja location represents $78.69 \%$ of the total percentage composition of palynomorphs recorded with Ikeja location having $21.31 \%$. This reflects the vegetation of the sampling area, with Ipaja having more Guinea savanna and swamp vegetation area flanked by streams and swamp. This agrees with previous reports that record of airborne pollen and spores reflects the vegetation characteristics of the study area (Anderson, 1980; Reddi and Reddi, 1985; Njokuocha, 2006). The Ikeja location had a lower record of palynomorphs due to vegetation removal. Pollen grains dominated over pteridophytes spores at both locations (Appendices 1-2) which is in accordance with the findings of Adeonipekun and John (2011), Aderniyi et al. (2014), Ajika et al. (2014) and Adeonipekun et al. (2016). The size of these fern spores places a limitation on their ability to be airborne. Two peaks of pollen counts were recognized at both locations. The first occurred in April (weeks 8 and 9) at Ipaja as a result of the sudden bloom of Amaranthaceae and the second peak occurred in June (week 
20) mainly due to Poaceae pollen contribution. Furthermore, the pollen count peaks at Ikeja were also recorded in April (week 10) and June (week 17) with Poaceae and Alchornea as the major contributors. Since Poaceae has been reported to be allergenic (Aboulaich, 2013; Adeniyi et al., 2017), necessary precautions are to be taken by hypersensitive individuals as regards the timing of these pollen peaks. According to Adeniyi et al. (2018), Amaranthaceae and Alchornea cordifolia have also been confirmed as allergenic therefore hypersentive individuals are to be conscious of their peak events. It appears that Ipaja location is partly responsible for supplying palynomorphs to Ikeja location when the aeroflora distribution pattern and the interval (one-two weeks) in peaks are considered. This may be due to the effect of wind speed which is a difficult parameter to measure since its effect can be dramatic in a short period of time (Valencia-Barrera et al., 2001). It may also be attributed to the impact of weather conditions on the release and dispersal of the pollen grains. As it was earlier reported that rainfall, wind speed, temperature and relative humidity are responsible for air-bone pollen per time (Dola et al., 2004).

Worthy of mention is the prevalence and abundant record of fungal spores at both locations, as previously observed by Adeonipekun et al. (2016). Much has been reported about the abundance and cosmopolitan nature of fungal spores and their associated allergenicity (runny nose, watery and itchy eye) and diseases of humans, domestic animals and plants (Burge and Rogers, 2008; Njokuocha and Ukeje, 2006; Essien et al., 2013). However, the fungal spores recorded at Ipaja was higher (406) than those recorded at Ikeja (113). This could be as a result of prevailing weather conditions as reported (Calleja et al., 1993) that increase in temperature and moisture content promotes fungal spore production and dispersal. Even though the allergenicity of most of these fungal spores have been studied in Europe and America, the dominant genus in Nigeria as recorded by Odebode et al. (2020) - Aspergillus - needs be studied further.

Factors such as temperature, rainfall, relative humidity and wind speed have been reported as major drivers in airborne palynomorphs distribution. Pollen sum always show positive correlation with temperature and wind speed and negative correlation with rainfall and relative humidity (Burge and Rogers, 2000; Stennet and Beggs, 2004; Dola et al., 2004; Adeniyi et al. (2014, 2017); Adeonipekun et al., 2016). From the values of the correlation coefficients, the weekly pollen sums at both locations were negatively correlated to relative humidity, which agrees with previous reports (Dola et al. 2004, Adeniyi et al. 2014). Relative humidity is negatively correlated $(r=-0.097)$ with the abundance of pollen in Ipaja. The coefficient of determination $\mathrm{r}^{2}=0.09$, which implies that $0.9 \%$ of the variation in weekly pollen sum in Ipaja can be predicted from this relationship. Unlike other reports, wind speed in the present work shows negative correlation for both locations, though the value for Ikeja is not statistically significant. Valencia-Barrera et al. (2010) also reported a negative wind speed impact on pollen in Leon, Spain and stated that wind speed is a very difficult parameter to measure, since its effect can be dramatic even in a short period of time.

Temperature is known to influence air borne pollen positively. The correlation value of temperature for Ikeja was negative and positive for Ipaja, but statistically insignificant. Ipaja had temperature correlation correlation of 0.053 (coefficient of determination is $r^{2}=0.003$ ), which implies that $03.3 \%$ of the variation in weekly pollen sum in Ipaja can be predicted from this relationship.

There is a significant correlation between weekly pollen sum, cold and catarrh, with correlation of 0.440 $(\mathrm{p}<0.026)$ in Ikeja. This implies that higher cases of cold and catarrh is associated with higher pollen grains in Ikeja and the probability of this correlation occurring is 26 time out of 1000 . There is no statistically significant correlation between weekly pollen sum in Ikeja and asthma However, the weekly pollen sum at Ipaja recorded a positive value with cold and catarrh but had a negative value with asthma cases, which suggests that pollen may not be responsible for the asthma cases recorded. Although there is the possibility of human error in data collection of pollinosis cases in the used private hospital. Also, the fact remains that very few persons visit the hospital to report such cases unless their cases were severe. It could also be that these pollen grains may not be allergenic in their natural state, as reported for some pollen types (Ahmad et al. 2004) but when exposed to pollutants, they release their allergenic proteins hence the need for more scientific studies to evaluate many pollen and spores in the tropics to ascertain their allergenicity. 


\section{Conclusions}

The study showed that there were remarkable changes in the weekly density of the palynomorphs recorded with two distinct peaks for each location. The major variation noticed in the aero-flora distribution at the two different sites studied suggests that the atmospheric concentration of pollen and spores are influenced not only by the meteorological factors. It is also a function of the frequency, density and abundance of plant species at a given locality as well as timing of flowering. Hypersensitive individuals are to take necessary precautions during these peaks. Since Poaceae, Alchornea cordifolia and Amaranthaceae are known to be allergenic, other taxa and dominant fungal spores in Nigeria need be studied because of their abundance at both locations. The pollinosis cases recorded had a more significant correlation value at Ikeja where lesser number of air-borne pollen grains were recorded than Ipaja. This could be that these cases were caused by fungal elements rather than pollen or that these pollen in their original states were not as allergenic compared to when impacted by other environmental pollutants. Hence, more study is needed to ascertain the effect of these pollen in their natural state.

\section{Authors' Contributions}

Both authors read and approved the final manuscript.

\section{Acknowledgements}

This research received no specific grant from any funding agency in the public, commercial, or not-forprofit sectors.

\section{Conflict of Interests}

The authors declare that there are no conflicts of interest related to this article.

\section{References}

Aboulaich N, Achmakh L, Bouziane H, Mar TM, Recio M, Kadiri M, ... Kazzaz M (2013). Effect of meteorological parameters on Poaceae pollen in the atmosphere of Tetouan (NW Morocco). International Journal of Biometeorology 57(2):197-205. https://doi.org/10.1007/s00484-012-0566-2?shared-article-renderer

Adedokun JA, Emofurieta WO, Adedeji OA (1989). Physical, mineralogical and chemical properties of Harmattan dust at Ile-Ife, Nigeria. Theoretical and Applied Climatology 40:161-169. https://doi.org/10.1007/BF00866179

Adekanmbi O, Ogundipe O (2010). Aeropalynological studies of the University of Lagos campus, Nigeria. Notulae Scientia Biologicae 2(4):34-39. https://doi.org/10.15835/nsb.2.4.5393

Adeniyi TA, Adeonipekun PA, Olowokudejo JD, Akande I (2017). Allergenicity of dominant aeropollen in Nigeria: Part I. Current Allergy and Clinical Immunology 30(4):264-269.

Adeniyi TA, Adeonipekun PA, Olowokudejo JD, Akande I (2018). Allergenicity of dominant aeropollen in Nigeria: Part II. Current Allergy and Clinical Immunology 31(3):178-183.

Adeniyi TA, Adeonipekun PA, Olowokudejo JD, Akande IS (2014). Airborne pollen records of Shomolu Local Government Area in Lagos State. Notulae Scientia Biologicae 6(4):428-432. https://doi.org/10.15835/nsb649355 
Adeonipekun PA (2012). Comparative Aeropalynology of Ota, Nigeria. Journal of Ecology and Natural Environment 4(12):303-313. https://doi.org/10.5897/JENE12.031

Adeonipekun PA, Agbalaya AB, Adeniyi T (2016). Aeropalynology of Ayetoro-Itele, Ota, South Western Nigeria: A preliminary study. Human Paleoecology in Africa 2:130-153.

Adeonipekun PA, John M (2011). Palynological investigation of haze dust in Ayetoro-itele Ota, Southwest Nigeria. Journal of Ecology and the Natural Environment 3(14):455-460. https://doi.org/10.5897/JENE11.082

Agashe SN (1994). Recent treads in aerobiology and immunology. Oxford and IBH Publishing Company, New Delhi pp 285.

Agwu COC (2001). A study of Niger Delta environment through airborne palynomorphs, Port Harcourt, Nigeria. Palaeoecology of Africa 27:191-205.

Agwu COC, Njokuacha RC, Mezue O (2004). The study of airborne pollen and spores circulating at 'Head Level' in Nsukka environment. Bio-Research 2(2):7-14. https://doi.org/10.4314/br.v2i2.28552

Agwu COC, Osibe EE (1992). Airborne palynomorphs of Nsukka during the months of February - April, 1990. Nigerian Journal of Botany 5:177-185.

Ajikah L, Ogundipe OT, Bamgboye O (2015). Palyno- logical survey of airborne pollen and spores in the University of Lagos, Akoka campus, Southwestern Nigeria. Ife Journal of Science 17(3):643-655.

Altintas DU, Karakoc GB, Yilmaz M, Pinar M, Kendirli SG, Cakan H (2004). The relationship between pollen counts and weather variables in East Mediterranean Coast of Turkey. Development Immunology 11. https://doi.org/10.1080/10446670410001670544

Andersen ST (1980). Influence of climatic variation on pollen season severity in wind pollinated trees and herbs. Grana 19:47-52. https://doi.org/10.1080/00173138009424986

Barnes C, Pacheco F, Landuyt J, Hu F, Portnoy J (2001). The effect of temperature, relative humidity and rainfall on airborne ragweed pollen concentrations. Aerobiologia 17(1):61-68. https://doi.org/10.1023/A:1007693032090

Boral D, Chatteriee S, Bhattacharya K (2004). The occurrence and allergising potential of airborne pollen in West Bengal, India. Annals of Agricultural and Environmental Medicine 11:45-52.

Burge HA, Rogers CA (2008). Outdoor allergens. Environmental Health Perspective 108:655-368.

Calleja M, Strick RM, Duzer D (1993). Atmospheric pollen content off West Africa. Review of Palaeobotany and Palynology 79(3-4):335-368. https://doi.org/10.1016/0034-6667(93)90029-T

Clay-Poole ST, Slesnick UL (1983). The beauty and biology of pollen. The American Biology Teacher 45:366-370.

Dale PJ, Clarke JB, Fontes EMG (2002). Potential for the environmental impact of transgenic crops. Nature Biotechnology 20:567-574. https://doi.org/10.1038/nbt0602-567

Delgado JD, Garcia Rodriguez OE, Diaz Rodriguez AM, Diaz Gonzalez JP, Explosito FJ, Cuevas Agullo E, ... Castillo $S$ (2010). Origin and SEM analysis of aerosols of aerosols in high mountain of Tenerife (Canary Islands). Natural Science 2(10):1119-1129.

Emberlin J, Mullins J, Corden J, Millington W, Brooke M, Savage M, Jones S (1997). The trend to earlier birch pollen seasons in the UK: a biotic response to changes in weather conditions?. Grana 36(1):29-33. https://doi.org/10.1080/00173139709362586

Erdtman G (1969). An introduction to the study of pollen grains and spores. Hafnar Publishing Company. New York pp 486.

Essien BC, Agwu COC (2013). Aeropalynological study of Anyigba, Kogi State, Nigeria. Standard Scientific Research and Essays 1(13):347-351.

Essien BC, Agwu COC, Taiga A (2014). A comparative analytical investigation of airborne palynomorphs within Kogi State University Teaching Hospital, Anyigba. Nigeria. Journal of Applied Sciences Research 2(1):136-142.

Essien BC, Aniama SO, Idachaba SO (2013). A study of derived savanna environment through airborne palynomorphs, Anyigba, Kogi State, Nigeria. Scholars Academic Journal of Bioscience 1(6):313-317.

Essien BC, Taiga A, Suleiman MN, Idachaba SO, Aniama SO, Edegbo E (2013). A study of airborne fungal spores of Anyigba, Kogi State, Nigeria. American Journal of Biomedical and life Sciences 1(4):70-77. https://doi.org/10.11648/j.ajbls.20130104.11

Faegri K, Iversen J (1989). Textbook of pollen analysis. John Wiley and Sons. New York pp 345.

Faegri K, Vander PL (1996). The principles of pollination ecology. Pergamon Press, New York pp 536.

Feher Z, Jarai-Komlodi M (1996). Relationship between airborne ragweed pollen concentration and the macrosynoptic weather types in Budapest, Hungary. Annals of Agricultural and Environmental Medicine 3:121-126. 
Fornaciari M, Bricchi E, Greco F, Fascini D, Giannoni C, Frenguelli G, Romano B (1992). Daily variations of Urticaceae pollen count and influence of meteoclimatic parameters in East Perugia during 1989. Aerobiologia 8(3):407-413.

Friedhoff LR, Ehrlich-Kantzky E, Grant JH, Meyers DA, Marsh DG (1986). A study of the human response to Lolium perenne (rye) pollen and its components. Journal of Allergy in Clinical Immunology 78:1190-1201. https://doi.org/10.1016/0091-6749(86)90271-X

Geodateyan VA (1977). The amount of pollen as a regulator of evolutionary plasticity of crosspollinating plants. Biological Sciences 234:93-196.

Hasnain SM, Fatima K, Al-Frayh A, Al-Sedainy S (2005). One-year pollen and spore calendars of Saudi Arabia AlKhobar, Abha and Hofuf. Aerobiologia 21:241-247. https://doi.org/10.1007/s10453-005-9000-0

Kaplan A (2004). Airborne pollen grains in Zonguldak, Turkey, 2001-2002. Journal of Integrative Plant Biology 46(6):668-674.

Longe A, Malomo S, Olorunniwo MA (1987). Hydrogeology of Lagos metropolis. Journal of African Earth Science 6:163174. https://doi.org/10.1016/0899-5362(87)90058-3

Majd A, Chehregani A, Moin M, Gholami M, Kohno S, Nabe T, Shariatzade MA (2004). The effects of air pollution on structures, proteins and allergenicity of pollen grains. Aerobiologia 20(2):111-118. https://doi.org/10.1023/B:AERO.0000032950.12169.38

Newhouse CP, Levetin E (2004). Correlation of environmental factors with asthma and rhinitis symptoms in Tulsa, OK. Annals of Allergy, Asthma \& Immunology 92(3):356-366. https://doi.org/10.1016/s1081-1206(10)61575-X

Njokuocha RC (2007). Airborne pollen grains in Nsukka, Nigeria. Grana 45(1):73-80. https://doi.org/10.1080/00173130600555797

Njokuocha RC, Osayi EE (2005). Airborne pollen and spore survey in relation to allergy and plant pathogens in Nsukka, Nigeria. Bio- Research 3(1):77-84. https://doi.org/10.4314/br.v3i1.28575

Njokuocha RC, Ukeje HO (2006). The study of airborne pollen precipitation in the University of Nigeria (Nsukka) Botanic garden. Bio-Research 4(2):88-93. https://doi.org/10.4314/br:v4i2.117357

Odebode A, Adekunle A, Stajich J, Adeonipekun P (2020). Airborne fungi spores distribution in various locations in Lagos, Nigeria. Environmental monitoring assessment 192(87):1-14. https://doi.org/10.1007/s10661-019-80383

Reddi CB, Reddi NS (1985). Relation of pollen concentration in air. Grana 24:109-113.

Richardson MD, Ellis M (2000). Clinical and laboratory diagnosis of systemic fungi infection. Hospital Medicine 61:61614.

Romero OE, Lange CB, Swap R., Wefer G (1999). Eolian-transported freshwater diatoms and phytoliths across the equatorial Atlantic record: Temporal changes in Saharan dust transport patterns. Journal of Geophysical Research 104(2):3211-3222. https://doi.org/10.1029/1999JC900061

Sanchez H, Bush RK (2001). A review of Alternaria alternate sensitivity. Revista Iberoamericana de Micologia 18:58-59.

Sowunmi MA (1973). Pollen grains of Nigeria plants: I. Woody species. Grana 13:145-186. https://doi.org/10.1080/00173137309429891

Sowunmi MA (1995). Pollen grains of Nigeria plants: II. Woody species. Grana 34:120-141. https://doi.org/10.1080/00173139509430002

Stennet PJ, Beggs PJ (2004). Pollen in the atmosphere of Sydney, Australia, and relationships with meteorological parameters. Grana 43:209-216. https://doi.org/10.1080/00173130410000758

Subiza J, Masiello MJ, Subiza JL, Jerez M, Hinojosa M, Subiza E (1992). Prediction of annual variations in atmospheric concentration of grass pollen. A method based on meteorological factors and grain crop estimates. Clinical and Experimental Allergy 22:540-546. https://doi.org/10.1111/j.1365-2222.1992.tb00163.x

Tauber H (1977). Investigations of aerial pollen transport in a forested area. Dansk Botanisk Arkiv 32(1):1-121.

Valencia-Barrera R, Comtois P, Fernandez-Gonzalez D (2001). Biogeography and bioclimatology in pollen forecasting. An example of grass in Leon (Spain) and Montreal (Canada). Grana 40:223-229. https://doi.org/10.1080/001731301317223259

Zillinsky FJ (1983). Common diseases of small grain cereals. A guide to identification. American Phytopathological Society, Minnesota, USA pp 126. 
Ibigbami T and Adeonipekun A (2020). Not Sci Biol 12(3):729-740

OPEN ACCESS The journal offers free, immediate, and unrestricted access to peer-reviewed research and scholarly work. Users are allowed to read, download, copy, distribute, print, search, or link to the full texts of the articles, or use them for any other lawful purpose, without asking prior permission from the publisher or the author.

(c) (P)

License - Articles published in Notulae Scientia Biologicae are Open-Access, distributed under the terms and conditions of the Creative Commons Attribution (CC BY 4.0) License.

(C) Articles by the authors; SHST, Cluj-Napoca, Romania. The journal allows the author(s) to hold the copyright/to retain publishing rights without restriction. 
Supplementary files

\begin{tabular}{|c|c|c|c|c|c|c|c|c|c|c|c|c|c|c|c|c|c|c|c|c|c|c|c|c|c|c|}
\hline \multicolumn{27}{|c|}{ Appendix 1. weekly pollen records for Ipaja location } \\
\hline Ipaja & & \multicolumn{3}{|c|}{ Feb } & \multicolumn{4}{|c|}{ Mar } & \multicolumn{5}{|c|}{ April } & \multicolumn{4}{|c|}{ May } & \multicolumn{4}{|c|}{ Jun } & \multicolumn{4}{|c|}{ Jul } & \multirow[t]{2}{*}{ Tota } \\
\hline Palynomorphs & Families & 1 & 2 & 3 & 4 & 5 & 6 & 7 & 8 & 9 & 10 & 11 & 12 & 13 & 14 & 15 & 16 & 17 & 18 & 19 & 20 & 21 & 22 & 23 & 24 & \\
\hline Alchornea cordifolia & Euphorbiaceae & 3 & 2 & 1 & 8 & & 2 & 10 & 6 & 5 & 13 & 2 & 1 & 6 & 2 & 5 & 2 & & 1 & 1 & 4 & & & 1 & & 75 \\
\hline Asteraceae & Asteraceae & & & & 1 & 3 & & & & 1 & & 4 & & 3 & & & & & & & & 4 & & & & 16 \\
\hline Amaranthaceae & Amaranthaceae & & & & & 10 & 20 & 150 & 222 & 170 & 130 & & & 8 & 15 & 11 & 33 & 17 & 5 & 15 & 15 & 6 & & 3 & 2 & 832 \\
\hline Casuarina sp. & Casuarinaceae & & & & & & & & & & & & & & & & & & & & 1 & & & & & 1 \\
\hline Cyperaceae & Cyperaceae & & & & & & & & 4 & 1 & 2 & & 2 & & 1 & & 2 & 1 & 2 & & 4 & 2 & 1 & 1 & & 23 \\
\hline Commelina & Commelinaceae & & & & & & & & & & & & & & & 2 & & & & & & & & & & 2 \\
\hline Euphorbiaceae & Euphorbiaceae & & & 2 & 2 & 4 & & & 2 & 2 & & & & & & & & & & & 2 & 1 & & & & 15 \\
\hline Elaeis guineensis & Euphorbiaceae & & & & & 2 & 3 & & 1 & 5 & 4 & 2 & & 1 & 1 & & 1 & & & 1 & 4 & 1 & & & & 26 \\
\hline Mimocaceae & Mimocaceae & & & & 2 & 2 & & & & & & & & & & 1 & & & 1 & & 3 & & & & & 9 \\
\hline Nymphae lotus & Nymphaeaceae & 1 & & 2 & & & & & & & & & & 3 & & & 5 & & 2 & & & & & & & 13 \\
\hline Poaceae & Poaceae & 15 & 16 & & 37 & 10 & 18 & 13 & 22 & 29 & 18 & 21 & 17 & 38 & 17 & 22 & 24 & 8 & 13 & 12 & 39 & 8 & 1 & & 3 & 401 \\
\hline Rubiaceae & Rubiaceae & & & & & & & & & & & & & & & & & & & & & 1 & & & & 1 \\
\hline Typha sp. & Typhaceae & & & & & & & & & & 1 & 1 & & & & & & & & & & & & & & 2 \\
\hline Weekly sum of pollen & & 19 & 18 & 5 & 50 & 31 & 43 & 183 & 257 & 214 & 166 & 30 & 30 & 59 & 36 & 36 & 67 & 26 & 24 & 29 & 72 & 23 & 2 & 5 & 6 & \\
\hline \multicolumn{27}{|c|}{ Appendix 2. weekly fungi and pteridophyte spores' records for Ipaja } \\
\hline Acrostichum aureum & Euphorbiaceae & & & & & & & & & & 4 & & 2 & & & 2 & 1 & & & 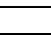 & 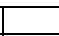 & & & & & 9 \\
\hline Cyclosorus afer & Thelypteridaceae & & & & & & 1 & & 1 & & & & & & 2 & 2 & & & & & & 1 & & & 1 & 8 \\
\hline Dryopteris sp. & Dryopteridaceae & & & & & & & & & & & & & & & & & 2 & & 1 & 3 & & & & & 6 \\
\hline Lagerstroemia & Lythraceae & & & & & & & & & & 1 & & & & & & & & & & & & & & & 1 \\
\hline Laevigate spore & & & & 1 & 3 & 4 & & & & & 1 & & & 2 & 1 & 1 & 1 & & & & 2 & & & & & 16 \\
\hline Lygodium sp & Lygodiaceae & & & & & & & & & & & 6 & 11 & & & & & & & & & & & & & 17 \\
\hline Monolete spore & & 3 & 1 & 2 & & & 2 & & & & & & 1 & & & & & & & & & & & & & 9 \\
\hline Nephrolepis sp. & Nephrolepidaceae & & & & & & & & & & 1 & & & & & & & & 1 & & 4 & 1 & 2 & & 1 & 10 \\
\hline Triporate spore & & & 3 & & 4 & & & 3 & 4 & 1 & & & & & & & & & & & & & & & & 15 \\
\hline Verrucate spore & & & & & 5 & & & & & & & & & & & & & & & & 1 & & & & & 6 \\
\hline Spore & & 3 & 2 & 4 & 4 & 6 & & & & & 1 & 7 & 1 & 24 & 10 & 8 & 9 & 1 & 1 & 8 & 14 & 4 & 3 & 1 & 1 & 112 \\
\hline Weekly sum of Spores & & 6 & 6 & 7 & 16 & 10 & 3 & 3 & 5 & 1 & 8 & 13 & 24 & 26 & 13 & 13 & 11 & 3 & 2 & 9 & 24 & 6 & 5 & 1 & 3 & \\
\hline Fungal spore & & 10 & 13 & 15 & 13 & 12 & 10 & 49 & & 39 & 11 & 18 & 8 & 33 & 10 & 11 & 36 & 17 & 26 & 20 & 30 & 7 & 5 & 4 & & \\
\hline
\end{tabular}




\begin{tabular}{|c|c|c|c|c|c|c|c|c|c|c|c|c|c|c|c|c|c|c|c|c|c|c|c|c|c|c|}
\hline \multicolumn{27}{|c|}{ Appendix 3. Weekly pollen records of Ikeja location } \\
\hline IKEJA & & \multicolumn{3}{|c|}{ Feb } & \multicolumn{4}{|c|}{ Mar } & \multicolumn{5}{|c|}{ Aprl } & \multicolumn{4}{|c|}{ May } & \multicolumn{4}{|c|}{ Jun } & \multicolumn{4}{|c|}{ Jul } & \multirow[t]{2}{*}{ Total } \\
\hline PALYNOMORPHS & FAMILIES & 1 & 2 & 3 & 4 & 5 & 6 & 7 & 8 & 9 & 10 & 11 & 12 & 13 & 14 & 15 & 16 & 17 & 18 & 19 & 20 & 21 & 22 & 23 & 24 & \\
\hline Alchornea cordifolia & Euphorbiaceae & 9 & 1 & 1 & 1 & 1 & 9 & 3 & 11 & & 13 & 6 & 1 & 5 & 5 & 5 & 8 & & 1 & 1 & 3 & 2 & & & & 86 \\
\hline Asteraceae & Asteraceae & & & & & & 2 & & & 1 & 2 & & & 1 & 1 & & & & & & & & & & & 7 \\
\hline Amaranthaceae & Amaranthaceae & 3 & & & 1 & & & & 3 & 2 & 5 & & & & 5 & & 3 & 2 & & & 1 & & 1 & 1 & 1 & 28 \\
\hline Casuarina & Casuarinaceae & & & & & & & & & & & & & & & & 1 & & & & & & & & & 1 \\
\hline Cyperaceae & Cyperaceae & 4 & & & & & & & & & & & 2 & & & & & 3 & 1 & 1 & 1 & 1 & & & & 13 \\
\hline Combretaceae & Combretaceae & & & & & & & & & 1 & & & & & & & & & & & & & & & & 1 \\
\hline Euphorbiaceae & Euphorbiaceae & & & & & & & & & & 1 & & & & & & & & & & & & & & & 1 \\
\hline Elaeis guineensis & Euphorbiaceae & & & & & & & & & 2 & & & & & & & & & & & & & & 2 & & \\
\hline Gomphena globosa & Amaranthaceae & & & & & & & & & & & & & & & & & & & & 1 & & & & & 1 \\
\hline Malvaceae & Malvaceae & & & & & & & & & & & 1 & & & & 1 & & & & & & & & & & 2 \\
\hline Moraceae & Moraceae & & & & & & & & & & & & 1 & & & & & & & & & & & & & 1 \\
\hline Mimocaceae & Mimocaceae & & & & & & 1 & & & & & & & & & & & & & & & & & & & 1 \\
\hline Nymphae lotus & Nymphaeaceae & 1 & & & & & & & & & & & & & & & & & & & & & & & & 1 \\
\hline Poaceae & $\begin{array}{l}\text { Poaceae } \\
\end{array}$ & 4 & 4 & 2 & 2 & 2 & 3 & 3 & 3 & 1 & 11 & 4 & 2 & 3 & 8 & 4 & 9 & 20 & 11 & 7 & 6 & 7 & 3 & 1 & 1 & 121 \\
\hline Sapotaceae & Sapotacaea & & 1 & & & & 2 & 1 & & & & & & & & & & & 2 & & & & & & & 6 \\
\hline \multirow[t]{2}{*}{ Tridax procumbens } & Asteraceae & & & & & & & & & & & & & & & & & & & 1 & & & & & & 1 \\
\hline & & & & & & & & & & & & & & & & & & & & & & & & & & \\
\hline \multirow{2}{*}{\multicolumn{2}{|c|}{ Weekly sum of pollen }} & & & & & & & & & & 1 & & & & & & & & & & & & & & & 1 \\
\hline & & 21 & 6 & 3 & 3 & 2 & 8 & 6 & 17 & 7 & 31 & 11 & 6 & 9 & 19 & 10 & 21 & 25 & 15 & 10 & 12 & 10 & 4 & 4 & 2 & \\
\hline \multicolumn{27}{|c|}{ Appendix 4. Weekly fungi and pteriodophyte spores' records for Ikeja } \\
\hline Acrostichum aureum & Acrostichaceae & 1 & & & & & & & 1 & 1 & & & & & & & & & & & & & 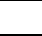 & . & & 3 \\
\hline Cyclosorus afer & Thelypteridaceae & & & & & & & & & & 2 & & & & & & & & & & & & 3 & 1 & & 6 \\
\hline Dryopterissp. & Dryopteridaceae & & & & & & & & & & 4 & & 1 & & 3 & 2 & 2 & 3 & 1 & 2 & 5 & 2 & & & 1 & 26 \\
\hline Fungal spore & & 9 & 8 & 3 & 1 & 4 & 1 & & 1 & 5 & 8 & 7 & 4 & 9 & 8 & 6 & 10 & 4 & 5 & 4 & 7 & 6 & 3 & & & 113 \\
\hline Lagerstromia & Lythraceae & & & & & & & & & & & & & & & & & & & & & & & & & \\
\hline Laevigate spore & & & & & 1 & & 4 & 2 & & & & 1 & & & 1 & & 3 & 4 & 1 & & & 1 & & & 1 & 19 \\
\hline Nephrolepissp. & Nephrolepidaceae & 1 & & & & & & & & & 1 & & & & & & & & & & & & 1 & & & 3 \\
\hline Polyporate & & & & & & & & 1 & & & & & & & & & & & & & & & & & & 1 \\
\hline Trilete spore & & & & & & 4 & 1 & & 3 & 1 & & & & & & & & & & & & & & & & 9 \\
\hline Verrucate spore & & & & & & & & & 2 & 1 & & & & & & & & & & & & & & & & 3 \\
\hline Spore Indeterminate & & 19 & 7 & 4 & 6 & 3 & 7 & & 4 & 2 & 8 & 3 & 3 & 1 & 4 & 4 & 3 & 2 & 4 & 4 & 4 & 3 & & 1 & & 96 \\
\hline Insect parts & & 3 & & & & & & & & & & & & & & & & & & & & & & & 1 & 4 \\
\hline \multicolumn{2}{|c|}{ Weekly sum of palynomorphs } & 54 & 21 & 10 & 12 & 14 & 30 & 10 & 28 & 17 & 5 & 22 & 14 & 19 & 35 & 22 & 39 & 38 & 26 & 20 & 28 & 22 & 11 & 6 & 5 & \\
\hline
\end{tabular}


Ibigbami T and Adeonipekun A (2020). Not Sci Biol 12(3)

Appendix 5. Reported cases of allergies (cold, catarrh and asthma) Adefemi hospital Ipaja Feb-Jul 2016

\begin{tabular}{|c|c|c|c|c|c|c|c|c|c|c|c|c|c|c|c|c|c|c|c|c|c|c|c|c|}
\hline $\begin{array}{c}\text { WKS } \\
\text { Cases }\end{array}$ & 1 & 2 & 3 & 4 & 5 & 6 & 7 & 8 & 9 & 10 & 11 & 12 & 13 & 14 & 15 & 16 & 17 & 18 & 19 & 20 & 21 & 22 & 23 & 24 \\
\hline $\begin{array}{c}\text { Cold } \\
\text { and } \\
\text { catarrh }\end{array}$ & 0 & 0 & 0 & 0 & 0 & 0 & 0 & 0 & 0 & 3 & 5 & 2 & 7 & 3 & 12 & 8 & 12 & 15 & 6 & 9 & 12 & 8 & 4 & 2 \\
\hline Asthma & 0 & 0 & 0 & 1 & 0 & 0 & 0 & 0 & 0 & 0 & 0 & 0 & 0 & 0 & 0 & 0 & 1 & 2 & 1 & 6 & 0 & 1 & 1 & 1 \\
\hline Total & 0 & 0 & 0 & 1 & 0 & 0 & 0 & 0 & 0 & 3 & 5 & 2 & 7 & 3 & 12 & 8 & 13 & 17 & 7 & 15 & 12 & 9 & 5 & 3 \\
\hline
\end{tabular}

